\title{
Towards the Europeanisation of trade unions in post-Communist Romania
}

\section{Introduction}

A fast-growing literature has been developed on employment relations, labour market reforms and social dialogue in central and east European countries. A common point is that these studies lay strong emphasis on the effets pervers of the 'triple transition' (Offe, 1992) of these countries as regards the development of trade unions in the region. In other words, the 1989 multi-level changes simultaneously encompass political, economic and socio-cultural issues. Therefore, this broad institutional and political remodelling challenges the political visibility of trade unions and their patterns of organisation and socialisation.

Much attention has been paid to the weak position of trade unions within this regional political arena (Petkov and Thirkell, 1991; Fairbrother and Clarke, 1994; Agh and Ilonszki, 1996; Cox and Mason, 2000; Pollert, 2000; Crowley and Ost, 2001). In this context of difficult organisational and functional emergence, scholars have focused their interest on several major issues. More specifically, as a starting point they have identified the changing roles of trade unions. The stake is linked to a deep process of the re-animation of old structures perverted by their involvement within the ancien regime. These specific origins have induced a quest for legitimacy with direct effects on the difficulties of trade unionism in articulating and representing interests. In parallel, trade unions have to focus on a complex relationship with governmental authorities and with employer organisations in the new tripartite framework.

Various studies have emphasised the major features of organised labour in central and eastern Europe. For example, Kubicek has underlined aspects like: de-unionisation; competition among and within trade unions; political marginalisation; the ineffectiveness of tripartite structures; the general lack of trust in organised labour; and the absence of trade unions in the new sectors of the economy (Kubicek, 1999). Therefore, note should be taken that these social actors are evolving and acting in a post-communist context marked by the urgent and complex need for reforms induced under the pressure of various international financial institutions as well as the European Union. From this point of view, the Romanian case does not make an exception.

This article aims at encompassing the Romanian context but from a different perspective. In a post-communist setting, which I would characterise as fragile in terms of its socio-economic development, EU requirements have induced a supplementary adaptation pressure concerning compliance with specific requirements in the area of employment and social policy. Thus, this article aims to discuss some developments affecting labour actors in the light of the European integration process. Moreover, the purpose of the article is to explore the responses that trade unions have provided and what they still have to provide in response to the EU pressure for adaptation, as well as how trade unions have been learning to face the challenges of European integration. I consider that, if from a legal and institutional point of view trade unions seem to have incentives for taking part in the transposition of EU demands, de facto the reality is much more complex and the responses diverse. In line with Coen and Dann- 
reuther (2003), in this article, I am interested in analysing in which manner Europeanisation as a 'guiding principle' allows for 'interpretation and incorporation' by national trade unions. I will refer more precisely to the opportunities created by European integration and the use that trade unions make of the complex mechanisms that impact not only on the national level, but also on the sectoral and local level of interest representation. My research is based on fieldwork realised in Romania as well as on the study of primary sources.

The article is structured in three main parts. In the first, I set the stage for my analysis by presenting some preliminary remarks concerning the landscape of the trade union movement in Romania and its most important features and challenges. In the second, I provide evidence about the processes at work in Romania during the stage of the transposition of the acquis on employment and social policy. Thirdly, I emphasise the multi-dimensional learning process of the EU's 'way of doing things' with which trade unions are confronted. Throughout the article, relevant examples of developments at national, sectoral and workplace level will guide my argumentation.

\section{Overview of trade unions in Romania: national and European actors}

Before approaching the thick of things, let me start by drawing an overview of Romanian trade unionism. During the communist period, trade unions did not have a solid tradition of operation: the communist regime reduced the social actors to simple 'transmission belts'. This is a common regional pattern but, in Romania, this feature is a deal more accentuated than in other countries in the region (Tigrid, 1981). In the early '90s, all countries from central and eastern Europe were rapidly engaging in a political and economic transition, with important consequences at social level. Some major challenges for the union movement in the Romanian case could be summarised as follows.

Firstly, de-industrialisation has been of major relevance for the reconstruction of trade unions as institutions/organisations in terms both of labour patterns of representation and of agents focused on influencing political agenda setting and decision-making. Economic reforms have implied huge systemic changes. Post-communist governments are involved in the management of several major tasks. Among these, the most important refer to the re-organisation of an obsolete industry, the creation of a private sector in the economy, the development of an entrepreneurial class and the reform of labour relations (van Zon, 1995).

Secondly, ownership changes have had a determining impact on the functioning of trade unions. Trade unions continue to be more strongly rooted in state-owned enterprises and are almost non-existent in the small and medium enterprises which are lately becoming increasingly creative of employment (Vaughan-Whitehead, 2003). Extensive research on this subject, such as, for example, the studies of VaughanWhitehead (2003) and Ost and Crowley (2001), demonstrate that the more private the economy, the less represented are trade unions. This is largely due to state-owned, or mixed ownership, enterprises inheriting a residual membership, while trade unionism has major problems in becoming institutionalised in newly-created SMEs. In sum, a major challenge for trade unions in the post-communist period is the issue of building membership.

In addition, the consequences of the new economic conditions do not favour the existence of very strong trade unions. Mainly, this is obvious when it comes to the 
rapid increase in unemployment rates. Indeed, overall, sensitive issues like massive workplace reduction and re-organisation, employment insecurity and the migration of an important part of the workforce outside the country remain important problems. These elements have a major impact on trade union membership. The issue of the fall in membership, which raises many questions about the effectiveness of union resources, is common to all central and eastern European countries in the post-communist period and it characterises the Romanian case too. Under these conditions, the post-communist socio-economic context determines a number of constraints that trade unions must handle and also tests union possibilities for interest representation.

From an organisational perspective, a pluralist framework for trade unionism developed shortly after 1989. At national level, a multitude of trade unions flourished at the beginning of the '90s. Over the years, these various organisations have suffered various fusions and fissions, eventually stabilising around five major organisations, presented in Table 1. At present, only these national confederations fulfil the criteria for representativeness established by the 2003 institutional framework: the National Confederation of Free Trade Unions of Romania - Frația (CNSLR-Frația); ${ }^{1}$ the National Trade Union Bloc (BNS); the National Confederation of Trade Unions 'Cartel Alfa' (CNS 'Cartel Alfa'); the National Confederation of Democratic Trade Unions of Romania (CSDR); and Confederation Meridian. ${ }^{2}$

1 Apart from these five main confederations, other trade unions partially fulfil the representative criteria and are sometimes admitted to negotiations and bargain freely with employer associations. One of the most eloquent examples is the Confederation of NonAligned Trade Unions, a confederation that has maintained, since its foundation (on 10 November 1993), independence and neutrality in respect of government, political parties and trade unions. There are also some strong federations at the sectoral level (in mining, education, commerce and health) and also some small trade unions that are not affiliated (C. Ciutacu, S. Pert and V. Vasile Rapport sur le dialogue social p. 7).

2 The Meridian confederation was formed in 1997 and replaces the Romanian Coal Workers Trade Union Confederation (CSMR), formed in 1991 by coal workers from the Jiu Valley. I did not succeed in obtaining much information about its operation and activities, but we did take note of the unanimous opinion of several trade union leaders from other confederations and federations that argued the marginal role of Meridian in the Romanian trade union movement. 
Table 1 - National representative confederations in Romania

\begin{tabular}{|l|l|l|l|}
\hline $\begin{array}{l}\text { Year of } \\
\text { establishment }\end{array}$ & Trade union & Membership & Represented sectors \\
\hline 1990 & $\begin{array}{l}\text { CNSLR- } \\
\text { Frația }^{1}\end{array}$ & $800000^{2}$ & $\begin{array}{l}\text { Represented in almost all economic } \\
\text { sectors }\end{array}$ \\
\hline 1991 & BNS & $375000^{3}$ & $\begin{array}{l}\text { Specialised in transport, energy, car } \\
\text { manufacturing, telecommunications, } \\
\text { health, public administration }\end{array}$ \\
\hline 1990 & Cartel Alfa & 325000 & $\begin{array}{l}\text { Specialised in mines, education, } \\
\text { banks, tourism, agriculture, transport, } \\
\text { public administration }\end{array}$ \\
\hline 1994 & CSDR & 345000 & $\begin{array}{l}\text { Specialised in education, health, food } \\
\text { industry, textiles }\end{array}$ \\
\hline 1994 & Meridian & 170000 & $\begin{array}{l}\text { Specialised in mining, metallurgy, } \\
\text { chemicals }\end{array}$ \\
\hline 1 & $\begin{array}{l}\text { CNSLR and Frația were, in the first years following the fall of the communist regime, } \\
\text { distinct organisations. In 1990, CNSLR was formed on the basis of the former com- } \\
\text { munist structures and, in the same year, Frația also emerged. They fused together in } \\
\text { 1993. } \\
\text { www.cnslr-fratia.ro } \\
\text { www.bns.ro }\end{array}$ \\
\hline
\end{tabular}

Source: Ciutacu, Pert and Vasile (2001); websites of confederations; Trif (2004).

In this national context, the steps taken by Romania on the road to membership of, and the obligations assumed for accession to, the European Union have important consequences for the functioning of trade unions. In order to analyse the impact of the European frameworks at domestic level, I consider it useful firstly to examine the relations that trade unions in Romania have developed with the European social actors. This could encourage some precision concerning the emergence and further development of unions' transnational activity.

In the '90s, the first entry gate into Europe was the demand for membership of the European Trade Union Confederation (ETUC). Starting with observer status, four of the five Romanian confederations have become full members of the ETUC. Moreover, a long time before the accession of the country to the EU, trade unions developed contacts with the European Economic and Social Committee.

Note should be taken that trade union education has been one of the key priorities of the partnerships between Romanian and European structures. The main objective has been to enhance trade unions' capacity to reform their internal structures, to participate in national decision-making and to learn to cope with the multiple obligations deriving from the EU integration process. For example, Romanian confederations are part of the trade union education network in central and eastern Europe, with the purpose of strengthening collaboration between the social actors in the region and Euro- 
pean/international confederations. Additionally, participation in the life of the representative European actors has facilitated strong bilateral collaborations between the Romanian unions and those from western countries, for example Germany or Belgium. An important outcome of a recent common project between CNSLR-Frația and ABVV (FGTB) Belgium has been the realisation of a practical guide for negotiation and union management as a helpful tool for coping with the accession challenges in the field.

Progressively, the sectoral federations have also participated in transnational activity. For example, in the energy sector, a large part of union federations are members of the European Mine, Chemical and Energy Workers' Federation (EMCEF), where the president of the Romanian federation from the oil industry acts as vicepresident, and of the European Federation of Public Service Unions (EPSU). If until now the international dimension has been mainly handled by the confederations, new developments in the sphere of employment relations have led to an acceleration of participation by the federations. The wave of privatisations in the energy sector and the presence of transnational companies in Romania has increased the Brussels-based activity of the sectoral federations. From my empirical work, I consider that, besides taking part in the international projects of the confederations to which they are affiliated, the federations are strongly involved in the campaigns of the European federations. This allows them to participate in projects directly related to the specificities of the sector they represent, but also to become aware of current challenges in the European energy sector. For example, the presence of Romanian representatives from the gas industry in the new European social dialogue committee in the natural gas sector, established in March 2007, has created the premises for a debate on the features and consequences of the unbundling of ownership at the domestic level. ${ }^{3}$ In this context, Romanian actors can take advantage of the advice provided by their western counterparts but can also offer a useful insight on their national situation and can react to transnational regulations.

In a nutshell, the partnership between national and European structures contributes to the diffusion of practice and to a learning process concerning the European 'way of doing things'. Up to now, unions have not established representation offices in Brussels, so membership of the European confederation and the federations represents the most important bridge linking them to the European Union.

\section{National responses to European demands}

After having briefly examined the insertion of Romanian unions in the European context, in this section I focus on the responses that trade unions have provided to the challenges induced by the process of European integration. In doing this, the empirical evidence will offer some illustrative examples.

3 Employee representatives from this sector are currently facing important transformations in line with EU energy policy. The most important objective for the energy sector in Romania is gradual market liberalisation. Ownership unbundling, in line with existing European legislation, has become a very controversial issue at domestic level; the separation of activities which underlies it is of great interest as trade unions are faced with a situation where their members are no longer part of the same company. 
In the literature on industrial relations in the new member states, Romania is mentioned almost exclusively in broader regional overviews. Moreover, these analyses focus exclusively on general issues, such as the new framework for industrial relations; the main organisational features of trade unions; the level of participation in the political process; the degree of penetration of social dialogue; and the emergence of tripartite institutions. However, few studies address the question of the responses of social actors during the European integration process, as well as their specific participation in the transformation of the institutional framework.

Moreover, in the Europeanisation literature, the industrial relations field has been under-studied. Most authors focus on an analysis of the European Social Model, questioning its emergence as a product of Europeanisation (Wincott, 2003), or of the development of European social actors like the ETUC and of transnational company bargaining (Visser, 1998). However, the focus of these studies has been less on how the social actors are coping with European rules and norms, especially in the context of EU accession, as has been the case for central and eastern European countries.

Radaelli (2003) defines Europeanisation as the existence of:

Formal and informal rules, procedures, policy paradigms, styles, 'ways of doing things', and shared beliefs and norms which are first defined and consolidated in the EU policy process and then incorporated in the logic of domestic (national and subnational) discourse, political structures and public policies.

The vast literature on Europeanisation has emphasised that two conditions are necessary for Europeanisation to take place: firstly, there must be a 'misfit' between European and domestic processes, Europeanisation being an 'inconvenience' (Borzel and Risse, 2003); secondly, at national level, there must be some facilitating factors be it actors, be it institutions - who respond to adaptation pressures (Borzel and Risse, 2003). Concerning the Europeanisation mechanisms at work in countries from central and eastern Europe, Grabbe refers to several categories:

The provision of legislative and institutional templates; money: aid and technical assistance; benchmarking and monitoring; advice and twinning; and gate-keeping: access to negotiations and further stages in the accession process. (Grabbe, 2003)

Moreover, as Grabbe puts it:

CEE applicants have no possibility of opt-outs from parts of the agenda. (Grabbe, 2003)

The broad conditions for accession to the EU are formulated in the well-known Copenhagen criteria. Based on this blueprint, the Commission's Regular Reports have analysed the progress of central and east European countries and thus, Romania's steps towards membership. However, in the area of social policy and employment, two particular approaches can be identified. First of all, Romania has had to transpose directives on labour law, such as those concerning labour disputes; the organisation of working time; information and consultation at the workplace level; etc. Also, Romania has had to adopt directives on the equal treatment of men and women; health and safety at work; and public health. At the sectoral level as well, one of the most important provisions adopted in the light of EU accession has been social legis- 
lation concerning European Works Councils (EWC). The implantation of European multinationals has accelerated the process of legislative changes regarding the transnational dimensions of union activities. In fact, a law concerning the constitution, organisation and functioning of European Works Councils was adopted in July 2005 (Law 217, 05/07/2005), a law that complies with the EU directive from 1994 and which entered into force on 1 January 2007. Accordingly, several terms have been transposed and defined, such as 'enterprise', 'Community-scale undertaking', and 'Community-scale group of undertakings'. Consequently, all these elements are part of the EU model and constitute the hard part of the acquis.

Secondly, the situation of social dialogue has been somewhat different. At European level, social dialogue was included in the acquis communautaire through the Single European Act (De Boer, Benedictus and van der Meer, 2005). Even so, the current European system of industrial relations is largely under-developed. One of the most important reasons is the diversity of national structures and traditions of industrial relations (Martin and Ross, 1999, De Boer, Benedictus and van der Meer, 2005). In this case, the EU does not provide a clear, specific model of integration: it provides instead softer legal provisions; thus, a softer conditionality. Consequently, regarding the provision of legislative and institutional templates (Grabbe, 2003), this softer conditionality has an impact on the consolidation of social dialogue. In fact, several Regular Reports of the Commission analysing progress in this domain have emphasised that social dialogue needs to be strengthened both at the national level and at the sectoral level. Nevertheless, no specific measures have been recommended.

In this context, these requirements are related to social dialogue focused mostly on the establishment of tripartite structures. As such, a complex process of institution building has been put in place, taking into account European guidelines for the existence of dialogue between the social partners. The role of the state is very important as it is the main actor involved in designing the framework for the national and regional functioning of social dialogue. At the beginning of the ' $90 \mathrm{~s}$, a tripartite secretariat for social dialogue was founded with the specific task of managing the PHARE programme for social dialogue. In 1997, the Economic and Social Council was institutionalised while, in parallel, commissions of social dialogue were established within the ministries and local administration. As in other central and east European countries, the tripartite institution gathers together representatives of the trade unions, employer associations and government. This structure has to promote projects and engage discussions on various topics, ranging from the negotiation of salaries to working conditions and so on.

The complex process of consolidating the social dialogue was strongly supported by the European Union. Within the framework of the PHARE programme, additional financial aid was provided for the promotion of the bipartite social dialogue and for an exchange of best practice between the Romanian actors and their western counterparts. Furthermore, the strengthening of the role of the Economic and Social Council was a priority of a specific twinning project started in 2004 over a period of 20 months, with the involvement of the Arbitration, Conciliation and Advisory Service (ACAS, Great Britain) and the Groupement d'intérêt public pour le développement de l'assistance technique et de la coopération internationale (GIP-inter) of the French Ministry of Employment and Social Affairs. The main objectives of the programme focused on the development of a training unit within the Romanian Economic and So- 
cial Council for the benefit of the social partners, as well as the reinforcement of the participation of the social partners in the implementation of legislation on the social dialogue.

However, in spite of the formal institutionalisation of the mechanisms of concertation, the results of social dialogue remain quite problematic: these structures have been reduced to a bogus body, a purely consultative institution for social and economic reform. Moreover, scholars specialised in this area have regularly identified this weakness. Concerning the participation of trade unions in this area, two elements can be revealed. Formally, trade unions have designated representatives in the institutions and have built a network of delegates handling social dialogue questions. Nevertheless, on various occasions, the reactions of trade unions to the practice of social dialogue have been mitigated. If there is a consensus in the literature concerning the marginalisation of the social actors by government representatives, this is an explanation which is clearly specific to the Romanian case. In fact, the perceptions of trade unionists concerning the tripartite institutions reveal that distrust in these mechanisms was established during the negotiations period; they refer to them as 'existing, but completely missing.' Furthermore, empirical evidence has demonstrated that, in many sensitive cases, trade unions circumvent the institutions of social dialogue, preferring more direct negotiation with the government. This largely indicates that the domestic actors, despite the impetus of European regulations, have appealed to other strategies for increasing their visibility and impact on decision-making. One of the most important of these is the direct involvement of trade union leaders in political life. ${ }^{4}$ Another shortcoming of the social dialogue institutions is the difficult consolidation of the employer side. This has been revealed by the literature on industrial relations in central and eastern Europe countries; regarding Romania, the extreme fragmentation of the employer associations has had negative effects on their autonomisation as de facto partners for trade unions.

The case of the workplace level of interest representation represents another useful example of the way in which trade unions cope with the demands of the EU. The most important legal provision adopted here by Romania refers to the directive on information and consultation from 2002. If at national and sectoral level the EU requirements have generated the elaboration of specific laws and institutions, this directive has not been made the subject of such an adoption. In an evaluation realised by the Economic and Social Council in 2005 concerning the information, consultation and participation of employees in Romania, its report reveals that, on this issue, the provisions of the Labour Code, of the law on trade unions and of the national agreement between the social partners and the government provide the legal framework. Even more important is that empirical findings lead me to believe that, in practice, trade unions have not demonstrated up to now a particular interest. In enterprises employing

4 The implication of trade union leaders in political life in Romania has been notable since the beginning of the ' $90 \mathrm{~s}$. The chances of having a political career by first being involved in a trade union are very high. Moreover, at public level, this has been made the object of criticisms concerning the ambiguous nature of trade unionism; considered to be a strategy of gaining a stronger impact on national decision-making, the outcomes of this involvement are mitigated, especially that the relations developed by trade unions with the political parties are not constant and change with systematic government turnovers. 
more than twenty people, none of them members of a trade union, employees have the right to elect their representatives. However, there are many situations, such as for example the case of SMEs, when no such form of interest representation exists. This is a reminder of a general characteristic at regional level regarding the difficulties of establishing labour organisations in a 'blank' territory without any history of unionism. However, there are cases when trade unions inhibit the development of such forms of interest representation. As one trade unionist stated:

Why do we need employee representatives? We represent them enough.

Consequently, trade unions have so far been opposed to an alternative form of representation. ${ }^{5}$ This example demonstrates that domestic actors shape the extent of the incorporation of European rules and practices. Even if the pressure for compliance with EU legislation is high, the social actors preserve at the local level the national pattern of interest representation. By voicing their specific preferences, it seems that trade unions have prevented the emergence of complementary forms of employee representation in the Romanian context.

\section{The use of 'Europe' by trade unions}

In this part of the article, I intend to provide a different perspective on the way in which trade unions in Romania have reacted in practice to European regulations. During the long road to membership, Romanian unions have learned progressively to make use of 'Europe' and of European debates in the national context. As Knill and Lehmkuhl have argued (2002), the:

European legislation may affect domestic arrangements by altering the domestic rules of the game. European influence is confined to altering domestic opportunity structures and hence the distribution of power and resources between domestic actors.

One relevant example is represented by the way in which trade unions integrated a European debate into a national decision-making procedure. In fact, in the context of the amendment of the Labour Code in 2005, trade unions strongly legitimised their opposition to several points by appealing to arguments expressed at the European level against the liberalisation of services in the internal market.

EU conditionality required the revision of a Labour Code that has been through only minor changes during the post-communist period; for different national reasons, this only took place in 2005. In this case, the trade unions adopted, for the first time, a common position but also made explicit references to the negative consequences of attempts at the liberalisation of employment relations in Romania. Their attitude was supported by a large mobilisation of members during participation at the European demonstration organised by the ETUC in Brussels in March 2005 against the Bolkestein directive. The perception of the social actors was that their European involvement would strengthen their national campaigns and demonstrations. During the Brussels event, trade unions expressed their opposition to the particular sensitive is-

5 Similar situations exist in Poland or Estonia and only in Hungary, Slovenia, Lithuania and Slovakia is there a dual system of representation. 
sue of the Labour Code in Romania. Based on my research on the ground, I have realised that participation in the European demonstration has to be considered with a caveat: many trade unionists established the reasons for their participation during their trip to Brussels. Nevertheless, this example illustrates not only the progressive process of the awareness of important European issues, but also that European debates have been incorporated into the national discourses of the social actors.

This example is illustrative of the learning process of how to make use of Europe. Another example of learning the 'way of doing things' is the case of the sectoral level of interest representation. A general under-development of this level has been emphasised by several research studies. Vaughan-Whitehead (2003) argued that tripartite negotiations are not doubled by serious autonomous dialogue. Indeed, in Romania agreements signed at the national level are often transposed to the sectoral and workplace levels without further negotiation. Still, trade unions are being increasingly confronted with transnational forms of negotiation and co-operation. This is the case in the energy sector, already mentioned.

In this sector, the arrival of foreign investors such as Gaz de France, Enel, E.ON or OMV has opened up an entirely new arena of transnational bargaining. European legislation on information and consultation demands the participation of employee representatives from all subsidiaries in the EWC of the community-scale enterprise. Consequently, trade unionists from the sector had to cope rapidly with the challenge of designating members and of incorporating the principles of the operation of this transnational forum of interest representation. In a preliminary phase, Romanian representatives had the difficult task of adjusting to the mechanisms underlying the activity of the EWC. Coming from a national context marked not only by the communist inheritance but also by the deep post-communist transformations, this included accommodation with the different negotiatory cultures, interests and priorities of their counterparts.

The involvement of trade union officials in these structures has created a new impetus for socialisation at the European level. In this context, the importance of informal contacts between Romanian and western representatives should not be neglected. The significance of these informal processes is two-fold. On the one hand, this allows a deeper understanding of the different domestic contexts and of analysing major issues like collective dismissals, professional re-training or the economic strategies of companies. On the other hand, this opens the way for new possibilities of building coalitions of interest at the transnational level. If the limited role of the EWC regarding the information and consultation of employee representatives undergoes severe criticisms, Romanian delegates have, nevertheless, made use of the opportunities offered by the European partnership.

One example stands for this account. At the initiative of the Romanian actors, a common project federating employee representatives from other European countries in which Gaz de France operates was developed in 2006; this culminated in October 2006, when the gas union federation from Romania hosted a conference and adopted a common social charter signed by delegates from Slovakia, Hungary, Italy and France. The project has the ambition of setting the stage for an eventual negotiation of a collective agreement at the multinational level. In my view, this clearly illustrates that Romanian social actors are not only the recipients of European norms and rules, but also important players trying to find their place in a transnational context. They 
provide feedback, take initiatives on relevant matters and, thus, are trying to 'upload' their preferences at European level.

The process of being 'Europeanised' has been doubled by a process of reform at the organisational level of trade unions. In response to the challenges of transnational forms of interest representation, unions in the energy sector have become involved in major internal restructuring. The presence of foreign companies has contributed strongly to the redefinition of the old personnel schemes of the monolithic state enterprises and so trade unions have developed new strategies for recruiting new members especially among young, recently recruited employees. The objectives of trade unions also change as they become aware of the necessity of having trained officials capable of handling issues of European interest. In fact, trade unions have expanded their field of negotiation with the employer side by focusing not only on the negotiation of salaries and collective agreements but also on defining clear training projects. If until now the training and development of staff have been realised mostly under the impulsion of European organisations, recently Romanian unions have taken the initiative of facilitating the training of their officials, especially on subjects concerning European legislation on social policy, patterns of interest representation in western countries or the role and scope of transnational structures of collective bargaining. Trade unions have become interested in building their expertise in order to take advantage of the possibilities created by the EU funds from which they have not yet benefited, lacking not only the material base but also specialised human resources. Moreover, as many trade unionists have declared, important steps have been made to fill in the technological gap in IT infrastructure and computer literacy in order to accustom the membership base with rapid information tools. Note should be taken that in the last few years alone, union websites have begun to develop, to be updated and to have more visibility at national and international levels.

\section{Instead of a conclusion: the ongoing process of Europeanisation}

In this article, I aimed to investigate how trade unions in Romania have responded to the challenges of European integration. Drawing on examples from empirical evidence, the analytical dimension of the literature on Europeanisation has allowed me to emphasise several aspects of the trade union response.

The pressure for adaptation induced by the road to membership has two main characteristics. On the one hand, the hard part of the acquis has been strictly supervised during the negotiations for accession. In the case of the directives to be transposed, monitoring refers to the changes in legislation and the adoption of new laws. On the other hand, in the social dialogue area, the soft conditionality has created the institutional framework for operation while the Regular Reports have mostly highlighted its practical aspects, its operational difficulties and its 'weak' character. In fact, the article illustrates that there is not a unique pattern of compliance. I have shown that the final outcome of this pressure for adaptation is shaped by the preferences of the actors, while a high degree of resistance can be identified at the local level of interest representation. Consequently, under the EU pressure for adaptation, the national actors have established a breathing space for deciding the scope and modalities of implementing European demands. Additionally, the social actors have benefited from the mechanisms of Europeanisation, most notably the infusion of financial assistance as well as its advice and twinning components. This has provided trade un- 
ions with new opportunities at the national level to assume the obligations of membership of the EU.

I have also tried to demonstrate that Romanian trade unions have made use of 'Europe' and have sought to incorporate its norms and beliefs, transposing them to the national context. Starting with a phase of accommodation to activity at the European level, to eventual membership of the European representative organisations, Romanian trade unions have become more and more involved in transnational activity. The European level has opened up a new arena for socialisation and this goes from involvement in European debates to encompassing them within domestic decision-making processes. The signs of Europeanisation are particularly relevant in the case of the energy sector. Thus, trade unions are still learning to handle the transnational mechanisms underlying the activity of European Works Councils, but the example also illustrates that domestic actors are voicing their positions within the European sphere. Consequently, this case indicates the bottom-up effects of the ongoing process of Europeanisation. Moreover, the exchanges created by transnational industrial relations have had an impact on the internal functioning of trade unions, encouraging reforms and establishing new priorities on their agenda.

\section{References}

Agh, A and G. Ilonszki (eds.) (1996) Parliaments and Organized Interests: The Second Steps Hungarian Centre for Democracy Studies.

Borzel, T and T. Risse (2003) 'Conceptualizing the Domestic Impact of Europe' in K. Featherstone and C. Radaelli (eds.) The Politics of Europeanization Oxford University Press

Ciutacu, C, S. Pert and V. Vasile (2001) Rapport sur le dialogue social en Roumanie, à la demande des partenaires sociaux européens CES/UNICE-UEAPME/CEEP.

Coen, D and C. Dannreuther (2003) 'Differentiated Europeanization: Large and Small Firms in the EU Policy Process' in K. Featherstone and C. Radaelli (eds.) The Politics of Europeanization Oxford University Press.

Cox, T and B. Mason (2000) 'Interest Groups and Tripartism in East Central Europe' European Journal of Industrial Relations 6(3).

Crowley, S. and D. Ost (eds.) (2001) Workers after Workers' States. Labor and Politics in Postcommunist Eastern Europe Maryland: Rowman \& Littlefield.

de Boer, R, H. Benedictus and M. van der Meer (2005) 'Broadening without Intensification: The Added Value of the European Social and Sectoral Dialogue' European Journal of Industrial Relations 11(1): 51-70.

Fairbrother, P and S. Clarke (1994) 'Post Communism and the Emergence of Industrial Relations in the Workplace' in R. Hyman and A. Ferner (eds.) New Frontiers in European Industrial Relations Basil Blackwell: London.

Featherstone, K and C. Radaelli (eds.) (2003) The Politics of Europeanization Oxford University Press.

Grabbe, H (2003) 'Europeanization Goes East: Power and Uncertainty in the EU Accession Process' in K. Featherstone and C. Radaelli (eds.) The Politics of Europeanization Oxford University Press. 
Knill, C and D. Lehmkuhl (2002) 'The National Impact of European Union Regulatory Policy: Three Europeanization Mechanisms' European Journal of Political Research 41: 255-280.

Kubicek, P. (1999) 'Organized Labor in Postcommunist States: Will the Western Sun Set on It, Too?' Comparative Politics 32(1): 83-102.

Martin, A and G. Ross (1999) 'In the Line of Fire: The Europeanization of Labor Representation' in A. Martin and G. Ross (eds.) The Brave New World of European Labor Berghahn Books: USA.

Offe, K (1992) 'Vers le capitalisme par construction démocratique? La théorie de la démocratisation et la triple transition en Europe de l'Est' Revue française de science politique 42(6): 923-42.

Petkov, K and J. Thirkell (1991) Labour Relations in Eastern Europe. Organizational Design and Dynamics Routledge.

Pollert, A (2000) 'Ten Years of Post-Communist Central Eastern Europe: Labour's Tenuous Foothold in the Regulation of the Employment Relationship' Economic and Industrial Democracy 21(2).

Tigrid, P (1981) Révoltes ouvrières à l'Est Ed. Complexe: Bruxelles.

Trif, A (2004) 'Overview of Industrial Relations in Romania' South-East Europe Review for Labour and Social Affairs 7(2): 43-64.

van Zon, H (1995) 'Alternative Scenarios for Central Europe' in J. Hausner, B. Jessop and K. Nielsen (eds.) Strategic Choice and Path-Dependency in Post-Socialism Institutional Dynamics in the Transformation Process Elgar: Aldershot, UK.

Vaughan-Whitehead, D (2003) EU Enlargement versus Social Europe?: the uncertain future of the European Social Model Elgar: Cheltenham, UK.

Visser, J (1998) 'Learning to Play: The Europeanisation of Trade Unions' in P. Pasture and J. Verberckmoes (eds.) Working-Class Internationalism and the Appeal of National Identity Berg: Oxford International Publishers.

Wincott, D (2003) 'The Idea of the European Social Model: Limits and Paradoxes of Europeanization' in K. Featherstone and C. Radaelli (eds.) The Politics of Europeanization Oxford University Press. 